\title{
MENAKAR PELUANG MUNCULNYA INOVASI DAERAH PASCA UNDANG-UNDANG 23 TAHUN 2014 \\ (Studi pada Hasil Diklatpim IV Kabupaten Pringsewu Provinsi Lampung)
}

\author{
Maulana Mukhlis \\ Program Studi Ilmu Pemerintahan FISIP Universitas Lampung, \\ Mahasiswa Doktoral Ilmu Pemerintahan Universitas Padjadjaran \\ Email : maulanamukhlis1978@gmail.com
}

\begin{abstract}
ABSTRAK
Lahirnya inovasi daerah sebagaimana diamanatkan oleh UU 23/2014 tentang Pemerintahan Daerah salah satunya ditentukan oleh kualitas kepemimpinan. Dalam upaya melahirkan pemimpin yang kuat dan mampu melahirkan inovasi, maka pada seluruh peserta diklat kepemimpinan (pada semua level eselon; I, II, III, dan IV) diharuskan membuat laporan proyek perubahan/inovasi daerah yang telah/ akan dilakukan di daerahnya pasca diklatpim. Tujuan penelitian ini adalah untuk mengetahui peluang (prospek) munculnya inovasi daerah di Kabupaten Pringsewu Provinsi Lampung dari hasil analisis terhadap tigapuluh tiga dokumen proyek perubahan/inovasi daerah dari peserta diklatpim IV tahun 2014. Kajian ini menggunakan metode deskriptif dengan menggunakan pendekatan kualitatif dan mengandalkan data sekunder dalam bentuk dokumen laporan proyek perubahan.

Hasil penelitian menunjukkan bahwa meskipun pelaksanaan diklatpim IV pada tahun 2014 di Kabupaten Pringsewu telah menggunakan pola baru dengan perubahan kurikulum, penekanan metode pembelajaran pada aspek pengalaman lapangan atau di tempat kerja, serta lahirnya inovasi bagi unit kerja yang telah/ akan dilakukan namun hanya terdapat tiga belas dari tigapuluh tiga proyek perubahan yang masuk dalam kategorisasi jenis inovasi. Proyek perubahan yang dihasilkan oleh peserta diklatpim IV masih berkisar pada upaya optimalisasi bukan pengembangan. Kreatifitas yang muncul dari pejabat eselon IV juga masih berkisar pada optimalisasi administratif yang sangat mungkin hal tersebut sudah diamanatkan dalam aturan teknis yang dikeluarkan pemerintah (pusat). Proyek perubahan dalam Diklatpim IV lebih merupakan kreatifitas individu dalam menjalankan tupoksi di unit kerja sehingga belum merupakan inovasi pimpinan sebagai dasar munculnya inovasi di daerah. Tentu terdapat variabel atau faktor lain
\end{abstract}

Cosmogov, Vol. 2 No. 1, April 2016 | 1 
sebagai ukuran atau dasar menilai porspek (peluang) munculnya inovasi daerah selain pada aspek kepemimpinan melalui penyelenggaraan diklatpim sebagai kasus dalam penelitian ini.

Kata Kunci : Inovasi Daerah, Kepemimpinan, Kabupaten Pringsewu

\section{ABSTRACT}

The birth of innovation region, as mandated by Law 23/2014 on Local Government is determined by the quality of leadership. In an effort to deliver a leader who strong and able to bring innovation, then the entire participant of Leadership Training (at all levels of echelon; I, II, III, and IV) are required to make a report of changing project/ innovation areas that have been / will be done in the region after the Leadership Training. The objectives of this study is to identify opportunities (leads) to the emergence of regional innovation in Pringsewu Regency, Lampung Province, from analyzes of thirty-three documents of region changing project / innovations of participants in Leadership Training IV in 2014. The study used a descriptive method using a qualitative approach and relied on secondary data in form of the documents of changing project reports.

The results showed that despite the implementation of Leadership Training IV in 2014 in District Pringsewu have used the new patterns with some curriculum changes, emphasis of learning methods on the aspects of field experience or at workplace, likewise the birth of innovation for unit that has been / will be done, however there are only thirteen of thirty-three changing projects that came into the categorization of innovation variety. The changing project reports that have been resulted by participant of Leadership Training IV are still revolve around some efforts to optimize not to development. Creativity that emerged from Echelon IV was also still revolved around the optimization of administrative, which is quite possibly it has been mandated in technical rules were issued by the central government. The changing project in Leadership Training IV is more likely individual creativity when they are running their main duties in work units, as a result, it is not a leader innovation as a foundation to the emergence of innovation in the region. Certainly, there are variables or other factors to measuring leads (opportunities) on the emergene of region innovation, beside on leadership aspect through the organization Leadership Training as the case on this study.

Keywords: Region Innovation, Leadership, Pringsewu Regency. 


\section{PENDAHULUAN}

Salah satu substansi perubahan dengan terbitnya Undang Undang No. 23 Tahun 2014 tentang Pemerintahan Daerah adalah peluang adanya inovasi daerah. Secara khusus, inovasi daerah ini diatur dalam pasal 386-390 sebagai bagian dari bentuk pembaharuan dalam rangka peningkatan kinerja penyelenggaraan pemerintahan daerah. Hal ini berarti akan mendorong bukan saja kepala daerah untuk berinovasi tapi juga aparatur sipil negara (ASN) di daerah untuk mengembangkan gagasan inovatif. Dalam perspektif kewenangan, peluang adanya inovasi daerah ini merupakan jawaban dari fakta keberagaman kondisi dan kemampuan daerah-daerah di Indonesia (termasuk kemampuan/kapasitas kepala daerah dan ASN-nya) yang selama ini cenderung diseragamkan.

Penyelenggaraan pemerintah daerah selama ini sampai dengan berlakunya UU 32/2004 sebenarnya juga sudah mengimplementasikan kebijakan otonomi daerah (desentralisasi) namun cenderung bercirikan simetris atau setara di setiap provinsi/ kabupaten/kota; kecuali NAD, DKI Jakarta, DIY dan Papua/Papua Barat sebagai daerah yang berstat us otonomi khusus yang merefleksikan asas desentralisasi asimetris. Dalam pelaksanaannya selama ini, kebijakan otonomi daerah masih memiliki sejumlah kelemahan, seperti: otonomi daerah hanya dipahami sebagai kebijakan yang bersifat institusional saja; perhatian dalam otonomi daerah hanya pada masalah pengalihan kewenangan dari pusat ke daerah, tetapi mengabaikan esensi dan tujuan kebijakan itu, otonomi tidak disertai dengan upaya peningkatan kemandirian dan prakarsa masyarakat di daerah sesuai dengan alam demokrasi ${ }^{1}$. Model desentralisasi simetris tersebut ternyata tidak selamanya merupakan formula yang efektif untuk memberi solusi terhadap masalah penyelenggaraan pemerintahan, pembangunan dan problem sosial yang kompleks di Indonesia.

Menurut Agus Dwiyanto dalam Kumorotomo $^{2}$ melihat besarnya keragaman antar daerah, pilihan kebijakan desentralisasi seragam yang telah dilaksanakan selama satu dekade terakhir ini perlu ditinjau kembali.

1. Johansyah dalam Safri Nugraha dkk. 2013. Desain Inovasi Pemerintahan Daerah. Malang: UB Press. Hal.3

2. Wahyudi Kumorotomo \& Widaningrum, Ambar. 2010. Reformasi Aparatur Negara Ditinjau Kembali. Yogyakarta: Gava Media dan JMKP \& MAP UGM. Hal.4 
Pertama, model desentralisasi yang seragam dalam keanekaragaman daerah yang mencolok bertentangan dengan hukum alam dan nilai yang terkandung dalam desentralisasi itu sendiri. Kedua, desentralisasi yang seragam mengabaikan kenyataan bahwa daerah memiliki tingkat kematangan, cakupan wilayah, potensi daerah, dan jumlah penduduk yang berbeda antara satu dengan lainnya. Ketiga, model desentralisasi seragam yang sekarang berlaku juga mempersulit daerah dalam pengembangan struktur birokrasi yang efisien dan aparatur yang profesional, mengingat kompetensi dan kebutuhan mereka yang berbedabeda.

Konsep keseragaman (desentralisasi simetris) yang melihat daerah sebagai obyek yang harus diperlakukan sama serta hanya memiliki kewenangan yang sama dan acapkali diatur melalui peraturan yang dikeluarkan oleh pemerintah pusat terbukti meniadakan potensi inovasi yang dimiliki oleh daerah. Dinamika permasalahan publik, dinamika wilayah, tantangan globalisasi menjadi alasan utama mengapa inovasi sebenarnya harus dilakukan. Hanya saja keberanian untuk melakukan inovasi masih menjadi kendala tersendiri, seolah-olah inovasi menjadi hal tabu bahkan memunculkan ketakutan karena tidak adanya aturan yang secara khusus memungkinkan adanya inovasi tersebut.
Penyelenggaraan pemerintahan daerah, dengan kondisi dan dinamika permasalahan daerah yang berbeda kemudian dijalankan murni dengan pendakatan ada atau tidaknya aturan yang mengatur tentang inovasi kewenangan ini. Akibatnya, penyelenggaraan pemerintahan daerah, meskipun didukung oleh keberadaan Aparatur Sipil Negara (ASN) atau pegawai atau gubernur/bupati/walikota yang potensial tidak memberikan kontribusi positif dalam memunculkan kekhasan pengelolaan pemerintahan daerah.

Kini dengan ditetapkannya UU No. 23 Tahun 2014 yang sebagian materinya diubah dengan Perpu No. 2 Tahun 2014 tentang Perubahan atas UU No. 23 Tahun 2014 dan ditegaskan dalam UU No. 9 Tahun 2015, pintu melakukan inovasi di daerah menjadi semakin jelas. Inilah yang ditunggutunggu karena undang-undang ini memahami hambatan utama inovasi yakni ketidakcukupan regulasi. Dengan asumsi bahwa inovasi adalah semua bentuk pembaharuan dalam penyelenggaraan pemerintahan daerah (Pasal 386 UU 23/2014), maka inisiatif inovasi daerah tersebut dapat berasal dari kepala daerah, anggota DPRD, aparatur sipil negara, perangkat daerah, maupun anggota masyarakat secara luas.

ASN dan pejabat perangkat daerah sebagai bagian dari aktor yang memiliki peluang memunculkan inisiatif inovasi selaras dengan 
keberadaan UU No. 5 Tahun 2014 tentang ASN dan UU No. 30 Tahun 2015 tentang Administrasi Pemerintahan. Undang-undang ini merupakan dasar dalam manajemen aparatur sipil negara yang bertujuan untuk membangun aparat sipil negara yang memiliki integritas, profesional dan netral serta bebas dari intervensi politik, juga bebas dari praktek KKN, serta mampu menyelenggarakan pelayanan publik yang berkualitas bagi masyarakat dengan melakukan inovasi dan pembaruan.

UU No. 5 Tahun 2014 juga menyebutkan bahwa jabatan Pegawai ASN terdiri dari 3 (tiga) jenis, yaitu Jabatan Pimpinan Tinggi (JPT), Jabatan Administrasi, dan Jabatan Fungsional. Jabatan-jabatan tersebut dibentuk dengan tujuan, pekerjaan dan tanggung jawab masing-masing. Pekerjaan dan tanggung jawab masing-masing jabatan disusun saling membantu dan melengkapi, bergerak bersama untuk mewujudkan visi dan misi organisasi pemerintahan yang bermuara pada terwujudnya tujuan pembangunan nasional Indonesia. Apabila salah satu dari jabatan tersebut tidak berkontribusi maksimal sesuai dengan peran dan tanggung jawabnya, berpotensi mempengaruhi kinerja organisasi dan menjadi beban bagi jabatan lain. Dalam rangka mewujudkan tujuan tersebut, maka kualitas kepemimpinan sektor publik (pemerintahan) menjadi kata kunci yang harus diwujudkan

Kepemimpinan di sektor publik utamanya pada pemerintahan merupakan suatu hal yang krusial. Keberhasilan pemerintah dalam mewujudkan tujuan bernegara salah satunya ditentukan oleh kualitas pemimpin pemerintahan. Hal ini sudah terbukti dari pengalaman negara-negara di seluruh dunia. Kemajuan negaranegara seperti Jepang, Korea Selatan, Cina, India, dan negara lainnya yang mengalami kemajuan pesat ditentukan oleh kepemimpinan yang ada di negara tersebut. Salah satu contohnya kita dapat melihat kemajuan yang luar biasa di Singapura pada saat dibawah kepemimpinan Perdana Menteri Lee Kuan Yew.

Selanjutnya, muncul pertanyaan bagaimana melahirkan pemimpin yang kuat dan mampu melahirkan inovasi tersebut. Secara teoritis, Gary ${ }^{3}$ menyatakan bahwa terdapat dua pendapat tentang pembentukan kepemimpinan. Pendapat pertama menyatakan bahwa pemimpin itu

3. Gary Yulk. 2010. Kepemimpinan dalam Organisasi, Edisi Ke-Lima. Jakarta: PT. Indeks. Hal.1 
dilahirkan. Aliran ini mendukung pendapat adanya bakat bawaan sejak lahir dari seorang pemimpin. Pendapat kedua menyatakan bahwa pemimpin itu dapat dibentuk. Aliran ini menjelaskan pemimpin bukan merupakan bakat bawaan tetapi dapat dibentuk melalui berbagai cara. Salah satu cara untuk pembentukan kemampuan kepemimpinan ini adalah melalui pendidikan dan pelatihan (diklat).

Salah satu diklat pembentukan dan pengembangan kepemimpinan di pemerintah Indonesia baik Pemerintah Pusat maupun Pemerintah Daerah adalah pendidikan dan pelatihan kepemimpinan (diklatpim) sesuai dengan Peraturan Kepala LAN Nomor 10,11,12, dan 13 Tahun 2013 tentang Pedoman Penyelenggaraan Pendidikan dan Pelatihan Kepemimpinan Tingkat I, II, III, dan IV. Menindaklanjuti UU 23 Tahun 2015, maka mulai tahun 2014 penyelenggaran diklatpim ini mengalami perubahan pola. Perubahan pola diklatpim diatur dalam Peraturan Kepala Lembaga Administrasi Negara (LAN). Peraturan tersebut menjelaskan perubahan pola diklat dilakukan untuk lebih meningkatkan kualitas, efisiensi dan efektivitas penyelenggaraan diklat serta menghasilkan gambaran tentang kreatifitas dari calon pejabat dan inovasi dari calon pejabat tersebut tentang bagaimana kreatifitasitudapatdiimplementasikan di daerahnya.

Salah satu tujuan diklatpim adalah untuk menghasilkan kreatifitas dan atau inovasi dari calon pejabat yang bersangkutan serta bagaimana kreatifitas atau inovasi itu dapat diimplementasikan di daerahnya dalam bentuk laporan proyek perubahan selaras dengan substansi inovasi yang diatur dalam Pasal 386 UU No. 23 Tahun 2014 tentang inovasi daerah. Berkaitan dengan relevansi ini, maka penulis tertarik untuk melakukan penelitian tentang peluang munculnya inovasi daerah di Kabupaten Pringsewu dikaitkan dengan proyek perubahan/inovasi yang telah dihasilkan oleh para pejabat eselon IV peserta diklatpim tahun 2014 yang lalu.

Dalam perspektif kreatifitas dan inovasi dari pemimpin siklusnya dimulai dari munculnya ide. Kreatifitas dan inovasi dari (calon) pejabat tersebut serta bagaimana kreatifitas itu dapat diimplementasikan di daerahnya dalam bentuk laporan proyek perubahan hakikatnya lahir dari ide. Noor (2013:113) mengungkapkan bahwa dalam proses inovasi sebagai sebuah siklus terdapat empat komponen yang berperan yaitu: idea generations and discovery, idea selection, idea implementation, and idea diffusion. Hal ini menunjukkan bahwa ide dalam bentuk laporan proyek perubahan dari seluruh peserta Diklatpim (yang notabene seluruhnya pejabat) akan sangat berpengaruh terhadap munculnya inovasi di daerah tersebut. 
Karena itu, berdasarkan paparan latar belakang di atas, maka dapat diutarakan pertanyaan penting yang akan di jawab dalam penelitian ini yaitu bagaimana peluang munculnya inovasi daerah dari para pejabat pemerintahan eselon IV di Kabupaten Pringsewu sebagaimana ketentuan dalam UU 23 Tahun 2014?

\section{TINJAUAN PUSTAKA}

\section{Konsep Inovasi dan Inovasi Pemerintahan}

Menurut Rogers ${ }^{4}$, menjelaskan inovasi sebagai "an idea, practice, or object perceived as new by the individual. Selain itu inovasi juga tidak terlepas dari beberapa hal antara lain:

a. Pengetahuan baru. Sebuah inovasi hadir sebagai pengetahuan baru bagi masyarakat dalam sebuah sistem sosial tertentu. Pengetahuan ini merupakan faktor penting penentu perubahan sosial yang terjadi dalam masyarakat.

b. Cara baru. Inovasi juga dapat berupa sebuah cara baru bagi individu atau sekelompok orang untuk memenuhi kebutuhan atau menjawab masalah tertentu. Cara baru ini merupakan pengganti cara lama yang sebelumnya berlaku.

c. Objek baru. Sebuah inovasi adalah objek baru bagi penggunanya, baik berbentuk fisik (berwujud/tangible) maupun yang tidak berwujud (intangible).

d. Teknologi baru. Inovasi sangat indentik dengan kemajuan teknologi. Banyak contoh inovasi yang hadir dari hasil kemajuan teknologi. Indikator kemajuan dari sebuah produk teknologi yang inovatif biasanya dapat langsung dikenali dari fitur-fitur yang melekat pada produk tersebut.

e. Penemuan baru. Hampir semua inovasi merupakan hasil penemuan baru. Sangat jarang ada kasus inovasi hadir sebagai sebuah kebetulan. Inovasi merupakan produk dari sebuah proses yang sepenuhnya bekerja dengan kesadaran dan kesengajaan.

Sedangkan Noor ${ }^{5}$ mengingatkan inovasi pemerintahan daerah adalah perpaduan dari lima komponen yaitu:

a. Strategy and Customers. Pemerintahan daerah harus tahu kapan, dimana, dan bagaimana inovasi itu dilakukan

4. Everett M. Rogers. 2003. Diffusion on Inovation: Five Edition. New York: The Free Press. Hal.12

5. Irwan Noor. 2013. Desain Inovasi Pemerintahan Daerah. Malang: UB Press. Hal.94 
b. Measures and Performance yaitu harus diketahui bagaimana mengukur keberhasilan inovasi yang dilakukan

c. Process (and Infrastructure), apakah inovasi yang dilakukan bersifat sementara atau menjadi bagian yang tak terpisahkan dari organisasi.

d. People, bagaimana budaya organisasi yang ada di dalam memahami inovasi tersebut.

e. Technology, bagaimana pemanfaatan alat dalam berinovasi tersebut

\section{Sifat dan Jenis Inovasi Pemerintahan}

Hiberman dalam Abdulhak ${ }^{6}$ membagi sifat perubahan dalam inivasi ke dalam enam kelompok inovasi yaitu Penggantian (substitution), Perubahan (alternation), Penambahan (addition), Penyusunan kembali (restructturing), Penghapusan (elimination), dan Penguatan (reinforcement)

Purwanto menjelaskan bahwa terdapat empat jenis inovasi pemerintahan, yaitu ${ }^{7}$ :
1. Inovasi kreatif, adalah program atau kebijakan inovasi yang rendah belum menunjukkan praktek positif di lapangan, cerdas dari segi gagasan dan berpotensi untuk menghasilkan efek langkah pendek yang positif.

2. Inovasi strategis, adalah program atau kebijakan inovatif yang cerdas berpotensi menghasilkan dampak jangka panajang yang positif tetapi belum terbukti implementatif di lapangan.

3. Inovatif produktif adalah program yang cerdas dari segi gagasan, berpotensimenghasilkan dampak jangka pendek yang pasif, terbukti implementasi di lapangan, namun belum cukup meyakinkan untuk jangka panjang.

\section{METODOLOGI}

Penelitian ini merupakan tipe penelitian kualitatif. Prosedur pengumpulan data sebagai usaha membatasi fokus penelitian dan mengumpulkan informasi dilakukan melalui pengumpulan dokumen kualitatif dan wawancara. Dokumendokumen kualitatif yang dikumpulkan

6. Abdulhak, I. 2002. Metode Pembelajaran Orang Dewasa. Bandung: Cipta Intelektual. Hal.9697

7. M. Ngalim Purwanto. 2000. Prinsip-Prinsip dan Teknik Evaluasi. Bandung: PT Remaja Rosdakarya. Hal.4 
adalah 33 (tiga puluh tiga) dokumen laporan proyek perubahan (inovasi) dari 33 (tiga puluh tiga) pejabat eselon IV pada Pemerintah Kabupaten Pringsewu peserta diklatpim IV, serta laporan hasil evaluasi diklatpim yang disusun oleh Badan Diklat Daerah Provinsi Lampung. Sedangkan wawancara mendalam dilakukan dengan Kepala Badan Diklat Daerah Provinsi Lampung dan dua orang pejabat di lingkup Pemerintah Kabupaten Pringsewu sebagai peserta diklatpim IV terbaik.

Sebagai fokus penelitian, enam kategorisasi sifat inovasi, yaitu penggantian (substitution), perubahan (alternation), penambahan (addition), penyusunan kembali (restructuring), penghapusan (elimination), dan penguatan (reinforcement) serta tiga jenis inovasi pemerintahan akan dijadikan rujukan. Setelah tahapan pengumpulan data dilalui, dilakukan analisis data secara kualitatif untuk menghasilkan data deskriptif tanpa menggunakan angka-angka. Dengan kata lain penelitian tidak hanya mengungkapkan kebenaran ide belaka, tetapi memahami kebenaran tersebut untuk dapat diimplementasikan di daerah. Untuk memperoleh tingkat kepercayaan hasil penelitian dilakukan uji validitas dengan mentriangulasi (triangulate) dan mengajak seorang auditor (external auditor) untuk mereview keseluruhan hasil penelitian ${ }^{8}$.

\section{HASIL DAN PEMBAHASAN}

\section{Deskripsi Pola Baru Pelaksanaan Diklatpim IV Kabupaten Pringsewu}

Diklat bagi aparatur sipil negara (ASN) di Kabupaten Pringsewu secara garis besar dapat dikelompokkan dalam dua jenis diklat yaitu diklat prajabatan dan diklat dalam jabatan. Diklatpim merupakan bagian dari diklat dalam jabatan. Diklatpim ini dilaksanakan untuk mencapai persyaratan kompetensi kepemimpinan aparatur pemerintah yang sesuai dengan jenjang jabatan struktural sebagaimana diatur dalam Peraturan Pemerintah Nomor 101 Tahun 2000 tentang Pendidikan dan Pelatihan Jabatan Pegawai Negeri Sipil. Lebih lanjut PP Nomor 101 tersebut menyebutkan diklatpim terdiri dari Diklatpim Tingkat IV, Tingkat III, Tingkat II, dan Tingkat I. Masing-

8. John W Creswell.2010. Research Design: Pendekatan Kualitatif, Kuantiotatif dan Mixed. Yogyakarta: Pustaka Pelajar. Hal.286 
masing jenis diklatpim tersebut diperuntukkan bagi jabatan struktural eselon IV, eselon III, eselon II, dan eselon I.

Mulai Tahun 2014, penyelenggaran diklatpim di Kabupaten Pringsewu mengalami perubahan pola dan diselenggarakan oleh Badan Diklat Provinsi Lampung. Perubahan pola diklatpim diatur dalam Peraturan Kepala Lembaga Administrasi Negara (LAN) Nomor 10, 11, 12, dan 13 Tahun 2013 tentang Pedoman Penyelenggaraan Pendidikan dan Pelatihan Kepemimpinan Tingkat I, II, III, dan IV. Peraturan tersebut menjelaskan perubahan pola diklat dilakukan untuk lebih meningkatkan kualitas, efisiensi dan efektivitas penyelenggaraan diklat. Beberapa alasan dilakukan perubahan pola diklatpim adalah (a) masih adanya kelemahan kurikulum, (b) metode pembelajaran kurang menekankan pada aspek pengalaman lapangan atau di tempat kerja, (c) kurangnya pembentukan karakter dan integritas, dan (d) kurangnya relevansi nyata dengan tidak munculnya inovasi bagi unit kerja.
Inti dari kompetensi kepemimpinan dalam diklatpim tersebut adalah membentuk pemimpin perubahan (Bahan Ajar Training of Facilitator Diklatpim LAN Tahun 2014). Filosofi pemimpin perubahan ini diilhami oleh konsep kepemimpinan adaptif (adaptive leadership) yang dikembangkan oleh Ronald Heifetz' Kebutuhan perlunya pemimpin adaptif karena adanya tantangan yang kompleks dan tidak cukupnya improvisasi operasional untuk menghadapi tantangan perubahan yang kompleks tersebut. Oleh karena itu, pemimpin perubahan yang akan dibentuk dalam diklatpim adalah pemimpin yang mampu melakukan adaptasi dengan perubahan yang terjadi di lingkungannya. Perubahan tersebut dilakukan dalam rangka mempertahankan organisasi dengan tingkat kinerja yang tinggi.

Untuk membentuk pemimpin perubahan dalam diklatpim, model pembelajaran dirancang dengan sistem on/off campuss. On campuss adalah model pembelajaran klasikal dengan penekanan pada penguatan wawasan kebangsaan dan integritas

9 Ronald Heifetz, Alexander Grashow, dan Marty Linski. 2009. The Practice of Adaptive Leadership Tools and Tactics for Changing Your Organization and The World. Massachusetts: Harvard Business School Publishing.hal.65 
serta pembekalan kemampuan teori manajerial dan kepemimpinan. Sedangkan Off campuss adalah model pembelajaran dengan pendekatan penerapan praktik kepemimpinan secara langsung di lapangan atau di tempat kerja para peserta diklat. Praktik lapangan dilakukan untuk mengasah kemampuan peserta dalam menyusun serta mengeksekusi rencana perubahan/inovasi yang telah disusun. Dengan kata lain, peserta diklat tidak hanya dilihat kemampuannya dari segi akademis selama on campuss, tetapi juga dilihat kemampuannya dalam membuat rencana perubahan/inovasi sampai dengan scenario bagaimana mengimplementasikan rencana perubahan/inovasi tersebut.

Dua model pembelajaran dalam diklatpim IV ini meliputi lima tahap. Kelima tahapan ini dilakukan dalam rangka mengembangkan kompetensi kepemimpinan peserta sebagai pemimpin yang mampu melakukan perubahan atau transformasi di tempat kerjanya;sebagaimana tergambar dalam tabel 1.

Tabel 1.

Tahapan Pembelajaran Diklatpim Pola Baru dan Kompetensi yang Diharapkan

\begin{tabular}{|c|c|c|}
\hline Tahapan & Model Pembelajaran & $\begin{array}{c}\text { Pengembangan Kompetensi } \\
\text { Kepemimpinan }\end{array}$ \\
\hline $\begin{array}{l}\text { Tahap I } \\
\text { Diagnosa } \\
\text { Kebutuhan } \\
\text { Perubahan } \\
\text { Organisasi }\end{array}$ & $\begin{array}{l}\text { On campuss dengan } \\
\text { penekanan pembelajaran } \\
\text { pada pengembangan } \\
\text { wawasan kebangsaan } \\
\text { dan integritas dan } \\
\text { diagnosa kebutuhan untuk } \\
\text { perubahan. }\end{array}$ & $\begin{array}{l}\text { Peserta mempunyai kemampuan } \\
\text { - Wawasan kebangsaan dan integritas } \\
\text { yang tinggi. } \\
\text { - Mendiagnosa permasalahan } \\
\text { organisasi dan mengidentifikasi } \\
\text { kebutuhan perubahan organisasi. }\end{array}$ \\
\hline $\begin{array}{l}\text { Tahap II } \\
\text { Breakthrough } \\
\text { I (Taking } \\
\text { Ownership) }\end{array}$ & $\begin{array}{l}\text { off campuss yaitu kembali } \\
\text { ke tempat kerjanya untuk } \\
\text { memperdalam kebutuhan } \\
\text { perubahan dan melakukan } \\
\text { komunikasi dengan } \\
\text { stakeholder. }\end{array}$ & $\begin{array}{l}\text { Peserta mempunyai kemampuan } \\
\text { mendiagnosa permasalahan dan } \\
\text { kebutuhan perubahan secara langsung } \\
\text { di kantornya dan mengkomunikasikan } \\
\text { kebutuhan perubahan kepada } \\
\text { stakeholder. }\end{array}$ \\
\hline $\begin{array}{l}\text { Tahap III } \\
\text { Merancang } \\
\text { Perubahan } \\
\text { dan } \\
\text { Membangun } \\
\text { Tim }\end{array}$ & $\begin{array}{l}\text { on campuss dengan } \\
\text { penekanan pembelajaran } \\
\text { pada penyusunan proposal } \\
\text { proyek perubahan yang } \\
\text { akan dilakukan. }\end{array}$ & $\begin{array}{l}\text { Peserta mempunyai kemampuan } \\
\text { merancang perubahan yang akan } \\
\text { dilakukan, membangun tim, dan } \\
\text { menjalin kemitraan dengan stakeholder } \\
\text { dalam rangka perubahan. }\end{array}$ \\
\hline
\end{tabular}




\begin{tabular}{|l|l|l|}
\hline \multicolumn{1}{|c|}{ Tahapan } & \multicolumn{1}{|c|}{ Model Pembelajaran } & \multicolumn{1}{c|}{$\begin{array}{c}\text { Pengembangan Kompetensi } \\
\text { Kepemimpinan }\end{array}$} \\
\hline $\begin{array}{l}\text { Tahap IV } \\
\text { Breaktrough } \\
\text { II } \\
\text { (Leadership } \\
\text { Labolatory) }\end{array}$ & $\begin{array}{l}\text { off campuss, peserta } \\
\text { mengimplementasikan } \\
\text { proyek perubahan di } \\
\text { tempat kerjanya. }\end{array}$ & $\begin{array}{l}\text { Peserta mempunyai kemampuan } \\
\text { eksekusi rencana, memobilisasi } \\
\text { stakeholder, dan mengatasi hambatan } \\
\text { yang muncul dalam pelaksanaan } \\
\text { perubahan }\end{array}$ \\
\hline $\begin{array}{l}\text { Tahap V } \\
\text { Evaluasi }\end{array}$ & $\begin{array}{l}\text { on campuss, peserta } \\
\text { mempresentasikan hasil } \\
\text { yang telah dicapai selama } \\
\text { implementasi proyek } \\
\text { perubahan. }\end{array}$ & $\begin{array}{l}\text { Terbentuk kompetensi sebagai } \\
\text { pemimpin perubahan atau } \\
\text { transformasional. }\end{array}$ \\
\hline
\end{tabular}

Sumber : Bahan Ajar pada Training of Facilitator Diklatpim, Lembaga Administrasi Negara. 2014

Implementasi kedua model pembelajaran serta kemampuan menyusun serta mengeksekusi rencana perubahan/inovasi tersebut dilakukan untuk menghasilkan pemimpin perubahan pada sektor pemerintah. Adanya tantangan internal di dalam pemerintahan yaitu belum optimalnya pelayanan publik yang diberikan pemerintah serta banyaknya kebutuhan untuk pengembangan daerah adalah faktor utama mengapa peserta diklatpim diharuskan memiliki kemampuan untuk menyusun rencana perubahan/inovasi di daerahnya. Tantangan eksternal atau dari luar daerah yakni kompetisi dengan daerah lain serta dari luar negeri yaitu globalisasi dan pasar bebas tentunya mengharuskan adanya kemampuan pemerintah sehingga memiliki daya saing yang tinggi yang diwujudkan - salah satunya- oleh kemampuan pejabat pemerintahan menghasilkan rencana perubahan/inovasi.

Sebagai daerah otonom baru, pelaksanaan Diklatpim IV kabupaten Pringsewu tahun 2014 merupakan diklat angkatan ke-4 sejak kabupaten ini berdiri dan diikuti oleh sebanyak 33 (tiga puluh tiga) pejabat eselon IV di lingkup pemerintah Kabupaten Pringsewu. Berdasarkan kewenangan, diklat tersebut dilaksanakan oleh Badan Diklat Daerah Provinsi Lampung. Sedangkan pelaksanaan diklatpim III bagi pejabat eselon III dilaksanakan oleh Badan Diklat Daerah Provinsi Lampung dengan menggabungkan peserta dari kabupaten/kota di Provinsi Lampung; tidak dilakukan tiap kabupaten sebagaimana penyelenggaraan

Diklatpim III. 


\section{Peluang Inovasi Daerah Berdasarkan Hasil Proyek Perubahan}

Pelaksanaan Diklatpim IV kabupaten Pringsewu tahun 2014 dilaksanakan selama dua bulan di kelas (on campuss) selama breakthrough I, dan dua bulan di tempat kerja (off campuss) untuk penerapan praktik dari proyek perubahan yang disusun oleh peserta diklatpim selama breakthrough II. Membuat Proyek perubahan merupakan salah satu kegiatan pada penyelenggaraan Diklatpim Tingkat IV yang dimaksudkan untuk memberi kesempatan kepada peserta untuk mengadakan perubahan nyata di unit kerja masing-masing.

Terdapat dua hal penting yang ditekankan oleh peserta diklatpim dalam membuat proyek perubahan yaitu menentukan kinerja organisasi yang akan ditingkatkan, dan upaya yang akan dilakukan untuk meningkatkan kinerja tersebut. Upaya-upaya tersebut dituangkan ke dalam jadwal kegiatan yang akan dilaksanakan peserta di unit kerja masing-masing selama breakthrough II. Proyek perubahan yang dihasilkan oleh peserta Diklatpim IV Kabupaten Pringsewu tahun 2014 sebagaimana terlihat dalam tabel 2.

Tabel 2.

Proyek Perubahan Peserta Diklatpim IV Kabupaten Pringsewu Tahun 2014

\begin{tabular}{|c|l|l|l|}
\hline No & \multicolumn{1}{|c|}{ Nama } & Instansi/Satuan Kerja & \multicolumn{1}{|c|}{ Judul Proyek Perubahan } \\
\hline 1 & Anisa Kartika Sari & $\begin{array}{l}\text { Badan Kepagawaian } \\
\text { Daerah }\end{array}$ & $\begin{array}{l}\text { Pengelolaan Database Pegawai } \\
\text { Menggunakan Sistem Berbasis } \\
\text { Teknologi }\end{array}$ \\
\hline 2 & Muhammad Zainudin & $\begin{array}{l}\text { Bagian Perlangkapan, } \\
\text { Sekretariat Kabupaten }\end{array}$ & $\begin{array}{l}\text { Optimalisasi Pengamanan Barang } \\
\text { Milik Negara Melalui Pemanfaatan } \\
\text { dan Pengendalian Aset Daerah }\end{array}$ \\
\hline 3 & Yuli Susanto & $\begin{array}{l}\text { Badan Pengelola } \\
\text { Keuangan Daerah }\end{array}$ & $\begin{array}{l}\text { Optimalisasi Pengelolaan } \\
\text { Administrasi Pengendalian } \\
\text { Kenaikan Gaji Berkala di } \\
\text { Lingkungan Daerah Kabupaten } \\
\text { Pringsewu }\end{array}$ \\
\hline 4 & Suroto & $\begin{array}{l}\text { Sekretariat Komisi } \\
\text { Pemilihan Umum }\end{array}$ & $\begin{array}{l}\text { Peningkatan Pengelolaan } \\
\text { Penatausahaan Barang Inventaris } \\
\text { Milik Negara pada Kantor KPU }\end{array}$ \\
\hline 5 & Dewi Komariyah & $\begin{array}{l}\text { Badan Pengelola } \\
\text { Lingkungan Hidup }\end{array}$ & $\begin{array}{l}\text { Penyusunan SOP } \\
\text { Pertanggungjawaban Keuangan } \\
\text { dalam Rangka Optimalisasi } \\
\text { Kinerja Petugas Pengelola } \\
\text { Keuangan }\end{array}$ \\
\hline
\end{tabular}




\begin{tabular}{|c|c|c|c|}
\hline No & Nama & Instansi/Satuan Kerja & Judul Proyek Perubahan \\
\hline 6 & Mardiyanto & $\begin{array}{l}\text { Dinas Perindustrian } \\
\text { dan Perdagangan }\end{array}$ & $\begin{array}{l}\text { Modernisasi Pembinaan Kemasan } \\
\text { Produk Makanan dalam Rangka } \\
\text { Penyelenggaraan Perlindungan } \\
\text { Konsumen }\end{array}$ \\
\hline 7 & Riduan A Hafid & Dinas Perhubungan & $\begin{array}{l}\text { Optimalisasi Pelayanan pada } \\
\text { Terminal Gading Rejo }\end{array}$ \\
\hline 8 & Trino & $\begin{array}{l}\text { Dinas Pemuda dan } \\
\text { Olahraga }\end{array}$ & $\begin{array}{l}\text { Peningkatan Pembinaan dan } \\
\text { Monitoring terhadap Para Pemuda } \\
\text { Berprestasi Bidang Cabang } \\
\text { Olahraga }\end{array}$ \\
\hline 9 & Gunawan Pratama & $\begin{array}{l}\text { Badan Kepegawaian } \\
\text { Daerah }\end{array}$ & $\begin{array}{l}\text { Realisasi Laporan } \\
\text { Pertanggungjawaban Keuangan } \\
\text { pada BKD }\end{array}$ \\
\hline 10 & Muhammad Taufik & $\begin{array}{l}\text { Badan Ketahanan } \\
\text { Pangan }\end{array}$ & $\begin{array}{l}\text { Peningkatan Mutu Pangan Melalui } \\
\text { Sosialisasi Pembinaan terhadap } \\
\text { para Produsen Bahan Pangan }\end{array}$ \\
\hline 11 & Suhardiyanto & $\begin{array}{l}\text { Dinas Pekerjaan } \\
\text { Umum }\end{array}$ & $\begin{array}{l}\text { Optimalisasi Pengelolaan } \\
\text { Administrasi Kepegawaian } \\
\text { terhadap Pegawai di Lingkungan } \\
\text { Dinas PU }\end{array}$ \\
\hline 12 & Ani Wijayanti & Kecamatan Pagelaran & $\begin{array}{l}\text { Optimalisasi Pengordinasiaon } \\
\text { Penyelenggaraan Pemerintahan } \\
\text { Pekon }\end{array}$ \\
\hline 13 & Putra Aditya Gumilang & Dinas Kominfo & $\begin{array}{l}\text { Optimalisasi Pemanfaatan Website } \\
\text { untuk Daya Saing Daerah di Era } \\
\text { E-Goverment }\end{array}$ \\
\hline 14 & Marwan & $\begin{array}{l}\text { Kecamatan Pringsewu } \\
\text { Barat }\end{array}$ & $\begin{array}{l}\text { Optimalisasi Penagihan Pajak } \\
\text { Bumi dan Bangunan (PBB) }\end{array}$ \\
\hline 15 & Kamsinah & $\begin{array}{l}\text { Kecamatan Gading } \\
\text { Rejo }\end{array}$ & $\begin{array}{l}\text { Optimalisasi Pelaksanaan } \\
\text { Pengelolaan Administrasi di } \\
\text { Bidang Pemberdayaan Masyarakat }\end{array}$ \\
\hline 16 & Adrea Marza & $\begin{array}{l}\text { Dinas Pekerjaan } \\
\text { Umum }\end{array}$ & $\begin{array}{l}\text { Optimalisasi Penyelenggaraan } \\
\text { Kegiatan Pemeliharaan dan } \\
\text { Fasilitasi Jalan dan Jembatan }\end{array}$ \\
\hline 17 & Purwantoro & Kecamatan Banyumas & $\begin{array}{l}\text { Optimalisasi Peran Keamanan } \\
\text { dan Ketertiban Masyarakat di } \\
\text { Kecamatan Banyumas } \\
\end{array}$ \\
\hline 18 & Endaryati & $\begin{array}{l}\text { Badan Penyuluh } \\
\text { Pertanian, Perkebunan, } \\
\text { Perikanan, dan } \\
\text { Kehutanan }\end{array}$ & $\begin{array}{l}\text { Revisi Sistem Evaluasi Pelaporan } \\
\text { Tenaga Penyuluh Pertanian dan } \\
\text { Kehutanan }\end{array}$ \\
\hline 19 & Budi Darmawan & Bappeda & $\begin{array}{l}\text { Optimalisasi Keterlibatan } \\
\text { Masyarakat dalam Proses } \\
\text { Perencanaan Pembangunan PNPM }\end{array}$ \\
\hline
\end{tabular}




\begin{tabular}{|c|c|c|c|}
\hline No & Nama & Instansi/Satuan Kerja & Judul Proyek Perubahan \\
\hline 20 & Ferza Ika Mahendra & Bagian Hukum & $\begin{array}{l}\text { Optimalisasi Pengendalian } \\
\text { Dokumentasi Produk Hukum } \\
\text { Menggunakan Teknologi Informasi }\end{array}$ \\
\hline 21 & Reka Pahlevi & Bagian Perencanaan & $\begin{array}{l}\text { Optimalisasi Pengendalian } \\
\text { Anggaran yang Bersumber } \\
\text { dari APBN dalam Penyusunan } \\
\text { Program dan Kegiatan Tahun } 2015 \\
\text { untuk Pembangunan Sarana dan } \\
\text { Prasarana Pasar }\end{array}$ \\
\hline 22 & Aprilia Hasbihaka & Kantor Kesbangpol & $\begin{array}{l}\text { Pengelolaan Arsip Kepegawaian } \\
\text { dengan Sistem Informasi Pegawai } \\
\text { Berbasis Aplikasi KOmputer }\end{array}$ \\
\hline 23 & Sidik Priyanto & Bagian Organisasi & $\begin{array}{l}\text { Optimalisasi dan Pengkoordinasian } \\
\text { LAKIP pada Sekretariat } \\
\text { Kabupaten Pringsewu }\end{array}$ \\
\hline 24 & Yopia Arnawatui & Inspektorat Kabupaten & $\begin{array}{l}\text { Penyusunan Rencana Kinerja } \\
\text { Anggaran Berdasarkan Wilayah } \\
\text { Kerja Inspektorat }\end{array}$ \\
\hline 25 & Dini Waryani & BPKAD & $\begin{array}{l}\text { Pengelolaan Administrasi Barang } \\
\text { di lingkungan BPKAD }\end{array}$ \\
\hline 26 & Judi Wulyana & $\begin{array}{l}\text { Kecamatan Pagelaran } \\
\text { Utara }\end{array}$ & $\begin{array}{l}\text { Sinkronisasi RKA Berdasarkan } \\
\text { Peraturan Bupati No. } 10 \text { Tahun } \\
2012 \text { tentang Pelimpahan Sebagian } \\
\text { Kewenangan Bupati kepada Camat }\end{array}$ \\
\hline 27 & Yeni Safitri & Dinas Koperasi & $\begin{array}{l}\text { Pemberdayaan Koperasi yang } \\
\text { Mempunyai Potensi untuk } \\
\text { dikembangkan melalui Pengelolaan } \\
\text { Manajemen Koperasi }\end{array}$ \\
\hline 28 & Eko Dharmafitria & BPMD & $\begin{array}{l}\text { Efektifitas Penyusunan Rencana } \\
\text { Kerja pada Lingkungan BPMD }\end{array}$ \\
\hline 29 & Bambang Sutrisno & Kecamatan Pagelaran & $\begin{array}{l}\text { Optimalisasi Tata Kelola Arsip } \\
\text { Kepegawaian }\end{array}$ \\
\hline 30 & Nurhidayat Suralaga & Sekretariat Korpri & $\begin{array}{l}\text { Revitalisasi Pelaksanaan } \\
\text { Pembinaan Mental dan Rohani } \\
\text { bagi Anggota Korpri }\end{array}$ \\
\hline 31 & Indra MIrza & Dispenda & $\begin{array}{l}\text { Optimalisasi Mekanisme } \\
\text { Penyusunan Laporan Realisasi } \\
\text { Pemeliharaan Pendapatan Daerah }\end{array}$ \\
\hline 32 & Ridho Wiradinata & $\begin{array}{l}\text { Bagian Humas dan } \\
\text { Protokol }\end{array}$ & $\begin{array}{l}\text { Akselerasi Penyampaian Berita } \\
\text { Berbasis Teknologi }\end{array}$ \\
\hline 33 & M. Subhan & BKD & $\begin{array}{l}\text { Peningkatan Informasi dan } \\
\text { Pelayanan Seleksi Penerimaan } \\
\text { Calon Praja di Lingkungan Pemda }\end{array}$ \\
\hline
\end{tabular}

Sumber : Laporan Hasil Diklatpim 4 Angkatan IV, 2014 
Everett M. Rogers ${ }^{10}$ mendefinisikan bahwa inovasi adalah suatu ide, gagasan, praktek atau objek/benda yang disadari dan diterima sebagai suatu hal yang baru oleh seseorang atau kelompok untuk diadopsi. Sedangkan Stephen Robbins ${ }^{11}$ mendefinisikan inovasi sebagai suatu gagasan baru yang diterapkan untuk memprakarsai atau memperbaiki suatu produk atau proses dan jasa. Sedangkan inovasi dalam perspektif administrasi negara adalah Proses memikirkan dan mengimpleentasikan suatu kebijakan oleh penyelenggara kepentingan publik untuk memenuhi kepentingan publik yang memiliki unsur kebaharuan serta kemanfaatan Sifat Perubahan dalam inovasi ada 6 kelompok yaitu: penggantian (substitution), perubahan (alternation), penambahan (addition), penyusunan kembali (restructturing), penghapusan (elimination), dan penguatan (reinforcement).

Dikaitkan dengan enam kelompok sifat inovasi tersebut, maka sebagian besar laporan proyek perubahan peserta Diklatpim IV Kabupaten Pringsewu di atas masuk kategori penambahan dan atau penguatan dengan kata kunci "optimalisasi". Hanya terdapat dua judul yaitu "Revisi Sistem Evaluasi Pelaporan Tenaga Penyuluh Pertanian dan Kehutanan" (judul no. 18) dan "Revitalisasi Pelaksanaan Pembinaan Mental dan Rohani bagi Anggota Korpri” (judul no. 30) yang masuk kategori penyusunan kembali. Meskipun demikian, pada kasus judul no. 30 tersebut, sangat mungkin ide proyek perubahan tersebut bukan merupakan kewenangan instansi (Sekretariat Korpri) karena upaya peningkatan dan pembinaan mental melalui pelatihan dan pembinaan bukan merupakan tugas pokok dan fungsi Sekretariat Korpri. Sedangkan pada sifat kategori penggantian, perubahan, dan penghapusan hampir tidak ditemui proyek perubahan yang relevan dengan kategori tersebut.

Secara umum, terdapat empat temuan terhadap laporan hasil proyek perubahan peserta Diklatpim IV Kabupaten Pringsewu. Pertama, kata kunci "optimalisasi" menunjukkan bahwa penyelenggaraan pemerintahan daerah di Kabupaten Pringsewu sebagai daerah otonom baru masih dalam tahap dasar pelayanan.. Kata

10. Rogers, Everett M. 1983. Diffusion on Inovation: Third Edition. New York: The Free Press. Hal.2

11. Stephen P. Robbins. 1994. Teori Organisasi: Struktur Desain dan Aplikasi. Jakarta: Arcan. Hal.2 
kunci "optimalisasi" menunjukkan bahwa upaya untuk meningkatkan penyelenggaraan pemerintahan berdasarkan tugas pokok dan fungsi (Tupoksi) setiap satuan kerja perangkat daerah di Kabupaten Pringsewu masih sangat diperlukan. Oleh karena itu, meskipun dalam perspektif inovasi sesuai standar LAN, hal ini merupakan kreatifitas, namun apabila dibandingkan dengan kabupaten/kota/daerah lain yang lebih maju maka akan sangat mungkin apa yang telah dan akan dilakukan di Kabupaten Pringsewu oleh para peserta Diklatpim IV sudah pernah dilakukan oleh kabupaten/kota/daerah lain tersebut, sehingga bukan lagi merupakan inovasi. Dalam kaitan ini, penyusunan proyek perubahan inovasi juga harus mempertimbangkan pengalaman-pengalaman daerah lain.

Kedua, pemahaman peserta diklatpim IV terhadap tugas pokok dan fungsi organisasi masih lemah. Hal ini ditunjukkan dengan masih ditemuinya proyek-proyek perubahan yang sebenarnya bukan merupakan Tupoksi lembaganya; kecuali jika Tupoksi tersebut digeneralisir (disempitkan) sebagai hanya sekedar tugas individu/pegawai/aparatur sipil negara. Tupoksi individu sebagai aparatur sipil negara tentu berbeda dengan Tupoksi lembaga (organisasi perangkat daerah).

Ketiga, kreatifitas yang muncul dalam proyek perubahan diklatpim IV di Kabupaten Pringsewu masih merupakan kreatifitas administratif misalnya dengan banyaknya judul "Penyusunan SOP(standar operasional prosedur)". Meskipun sebenarnya terdapat tiga judul yang sudah mengarah ke modernisasi misalnya Judul Pengelolaan Database Pegawai Menggunakan Sistem Berbasis Teknologi, Optimalisasi Pengendalian Dokumentasi Produk Hukum Menggunakan Teknologi Informasi, dan Akselerasi Penyampaian Berita Berbasis Teknologi, namun judul terakhir memang merupakan Tupoksi dari SKPD tersebut sehingga juga belum seluruhnya merupakan proyek inovasi. Selain implementasi dari proyek perubahan tersebut membutuhkan dukungan prasayarat teknologi, dalam perspektif administratif, masih sangat mungkin bahwa proyek perubahan yang diusulkan/dilakukan dalam bentuk SOP tersebut sudah diatur secara khusus dalam peraturanperaturan yang lebih tinggi. Namun, karena sebelumnya tidak dilakukan kajian regulasi terhadap usulan proyek perubahan, hal ini belum dapat diketahui.

Keempat, dalam perspektif kreatifitas, secara internal di kabupaten Pringsewu, proyek perubahan yang dilakukan oleh peserta Diklatpim IV Kabupaten Pringsewu sebagian besar sebenarnya telah memenuhi kriteria sebagai sebuah kreatifitas (melakukan sesuatu yang belum dilakukan ASN lain di Kabupaten Pringsewu). Namun dalam perspektif lahirnya inovasi daerah Kabupaten Pringsewu dari 
proyek perubahan tersebut belum menunjukkan potensi yang besar untuk muncul.

\section{Peluang Inovasi Daerah \\ Berdasarkan Hasil Proyek Perubahan}

Selanjutnya, dengan menggunakan tiga kategorisasi jenis inovasi

Tabel 3.

Kategorisasi Jenis Inovasi dari Proyek Perubahan Peserta Diklatpim IV

\begin{tabular}{|c|c|c|c|c|c|c|}
\hline \multirow[b]{2}{*}{ Jenis Inovasi } & \multicolumn{2}{|r|}{ Proyek Perubahan } & \multicolumn{2}{|c|}{ Good } & \multicolumn{2}{|c|}{ Good } \\
\hline & No & Judul & Gagasan & Praktik & $\begin{array}{l}\text { Efek Jangka } \\
\text { Pendek }\end{array}$ & $\begin{array}{c}\text { Efek } \\
\text { Jangka } \\
\text { Panjang }\end{array}$ \\
\hline Kreatif & 3 & $\begin{array}{l}\text { Optimalisasi Pengelolaan } \\
\text { Administrasi Pengendalian } \\
\text { Kenaikan Gaji Berkala } \\
\text { di Lingkungan Daerah } \\
\text { Kabupaten Pringsewu }\end{array}$ & $\mathbf{V}$ & - & $\overline{\mathbf{V}}$ & - \\
\hline & 4 & \multicolumn{5}{|c|}{$\begin{array}{l}\text { Peningkatan Pengelolaan Penatausahaan Barang Inventaris Milik Negara pada } \\
\text { Kantor KPU }\end{array}$} \\
\hline & 13 & \multicolumn{5}{|c|}{$\begin{array}{l}\text { Optimalisasi Pemanfaatan Website untuk Daya Saing Daerah di Era } \\
\text { E-Goverment }\end{array}$} \\
\hline & 20 & \multicolumn{5}{|c|}{$\begin{array}{l}\text { Optimalisasi Pengendalian Dokumentasi Produk Hukum Menggunakan } \\
\text { Teknologi Informasi }\end{array}$} \\
\hline & 22 & \multicolumn{5}{|c|}{$\begin{array}{l}\text { Pengelolaan Arsip Kepegawaian dengan Sistem Informasi Pegawai Berbasis } \\
\text { Aplikasi Komputer }\end{array}$} \\
\hline & 30 & \multicolumn{5}{|c|}{ Revitalisasi Pelaksanaan Pembinaan Mental dan Rohani bagi Anggota Korpri } \\
\hline & 31 & \multicolumn{5}{|c|}{$\begin{array}{l}\text { Optimalisasi Mekanisme Penyusunan Laporan Realisasi Pemeliharaan } \\
\text { Pendapatan Daerah }\end{array}$} \\
\hline \multirow[t]{6}{*}{ Strategik } & 1 & $\begin{array}{l}\text { Pengelolaan Database } \\
\text { Pegawai Menggunakan } \\
\text { Sistem Berbasis Teknologi }\end{array}$ & $\mathbf{V}$ & - & $\mathbf{V}$ & $\mathbf{V}$ \\
\hline & 2 & \multicolumn{5}{|c|}{$\begin{array}{l}\text { Optimalisasi Pengamanan Barang Milik Negara Melalui Pemanfaatan dan } \\
\text { Pengendalian Aset Daerah }\end{array}$} \\
\hline & 18 & \multicolumn{5}{|c|}{ Revisi Sistem Evaluasi Pelaporan Tenaga Penyuluh Pertanian dan Kehutanan } \\
\hline & 19 & \multicolumn{5}{|c|}{$\begin{array}{l}\text { Optimalisasi Keterlibatan Masyarakat dalam Proses Perencanaan } \\
\text { Pembangunan PNPM }\end{array}$} \\
\hline & 26 & \multicolumn{5}{|c|}{$\begin{array}{l}\text { Sinkronisasi RKA Berdasarkan Peraturan Bupati No. } 10 \text { Tahun } 2012 \text { tentang } \\
\text { Pelimpahan Sebagian Kewenangan Bupati kepada Camat }\end{array}$} \\
\hline & 32 & \multicolumn{5}{|c|}{ Akselerasi Penyampaian Berita Berbasis Teknologi } \\
\hline
\end{tabular}

(kreatif, strategic, dan produktif), dari tigapuluh tiga laporan hasil proyek perubahan peserta Diklatpim IV Kabupaten Pringsewu tahun 2014 dapat dikategorisasikan ke dalam pengelompokan sebagaimana tabel 3 . 


\begin{tabular}{|c|c|c|c|c|c|c|}
\hline \multirow[b]{2}{*}{ Jenis Inovasi } & \multicolumn{2}{|r|}{ Proyek Perubahan } & \multicolumn{2}{|c|}{ Good } & \multicolumn{2}{|c|}{ Good } \\
\hline & No & Judul & Gagasan & Praktik & $\begin{array}{l}\text { Efek Jangka } \\
\text { Pendek }\end{array}$ & $\begin{array}{c}\text { Efek } \\
\text { Jangka } \\
\text { Panjang }\end{array}$ \\
\hline Produktif & 6 & $\begin{array}{l}\text { Modernisasi Pembinaan } \\
\text { Kemasan Produk } \\
\text { Makanan dalam Rangka } \\
\text { Penyelenggaraan } \\
\text { Perlindungan Konsumen }\end{array}$ & $\mathbf{V}$ & $\mathbf{V}$ & $\mathbf{V}$ & - \\
\hline \multirow[t]{19}{*}{$\begin{array}{l}\text { Lainnya } \\
\text { (Tidak } \\
\text { Termasuk } \\
\text { Ketiganya) }\end{array}$} & 5 & $\begin{array}{l}\text { Penyusunan SOP } \\
\text { Pertanggungjawaban } \\
\text { Keuangan dalam Rangka } \\
\text { Optimalisasi Kinerja } \\
\text { Petugas Pengelola } \\
\text { Keuangan }\end{array}$ & - & - & - & - \\
\hline & 7 & \multicolumn{5}{|c|}{ Optimalisasi Pelayanan pada Terminal Gading Rejo**) } \\
\hline & 8 & \multicolumn{5}{|c|}{$\begin{array}{l}\text { Peningkatan Pembinaan dan Monitoring terhadap Para Pemuda Berprestasi } \\
\text { Bidang Cabang Olahraga }\end{array}$} \\
\hline & 9 & \multicolumn{5}{|c|}{ Realisasi Laporan Pertanggungjawaban Keuangan pada BKD } \\
\hline & 10 & \multicolumn{5}{|c|}{$\begin{array}{l}\text { Peningkatan Mutu Pangan Melalui Sosialisasi Pembinaan terhadap para } \\
\text { Produsen Bahan Pangan }\end{array}$} \\
\hline & 11 & \multicolumn{5}{|c|}{$\begin{array}{l}\text { Optimalisasi Pengelolaan Administrasi Kepegawaian terhadap Pegawai di } \\
\text { Lingkungan Dinas PU }\end{array}$} \\
\hline & 12 & \multicolumn{5}{|c|}{ Optimalisasi Pengordinasiaon Penyelenggaraan Pemerintahan Pekon } \\
\hline & 14 & \multicolumn{5}{|c|}{ Optimalisasi Penagihan Pajak Bumi dan Bangunan (PBB) } \\
\hline & 15 & \multicolumn{5}{|c|}{$\begin{array}{l}\text { Optimalisasi Pelaksanaan Pengelolaan Administrasi di Bidang Pemberdayaan } \\
\text { Masyarakat }\end{array}$} \\
\hline & 16 & \multicolumn{5}{|c|}{$\begin{array}{l}\text { Optimalisasi Penyelenggaraan Kegiatan Pemeliharaan dan Fasilitasi Jalan dan } \\
\text { Jembatan }\end{array}$} \\
\hline & 17 & \multicolumn{5}{|c|}{$\begin{array}{l}\text { Optimalisasi Peran Keamanan dan Ketertiban Masyarakat di Kecamatan } \\
\text { Banyumas }\end{array}$} \\
\hline & 21 & \multicolumn{5}{|c|}{$\begin{array}{l}\text { Optimalisasi Pengendalian Anggaran yang Bersumber dari APBN dalam } \\
\text { Penyusunan Program dan Kegiatan Tahun } 2015 \text { untuk Pembangunan Sarana } \\
\text { dan Prasarana Pasar }\end{array}$} \\
\hline & 23 & \multicolumn{5}{|c|}{$\begin{array}{l}\text { Optimalisasi dan Pengkoordinasian LAKIP pada Sekretariat Kabupaten } \\
\text { Pringsewu }\end{array}$} \\
\hline & 24 & \multicolumn{5}{|c|}{$\begin{array}{l}\text { Penyusunan Rencana Kinerja Anggaran Berdasarkan Wilayah Kerja } \\
\text { Inspektorat }\end{array}$} \\
\hline & 25 & \multicolumn{5}{|c|}{ Pengelolaan Administrasi Barang di lingkungan BPKAD } \\
\hline & 27 & \multicolumn{5}{|c|}{$\begin{array}{l}\text { Pemberdayaan Koperasi yang Mempunyai Potensi untuk dikembangkan } \\
\text { melalui Pengelolaan Manajemen Koperasi }\end{array}$} \\
\hline & 28 & \multicolumn{5}{|c|}{ Efektifitas Penyusunan Rencana Kerja pada Lingkungan BPMD } \\
\hline & 29 & \multicolumn{5}{|c|}{ Optimalisasi Tata Kelola Arsip Kepegawaian } \\
\hline & 33 & \multicolumn{5}{|c|}{$\begin{array}{l}\text { Peningkatan Informasi dan Pelayanan Seleksi Penerimaan Calon Praja di } \\
\text { Lingkungan Pemda }\end{array}$} \\
\hline
\end{tabular}

Sumber : Analisis Hasil Wawancara \& Review Auditor Eksternal 
Makna jenis Inovasi kreatif adalah program atau kebijakan inovasi yang rendah belum menunjukkan praktek positif di lapangan, cerdas dari segi gagasan dan berpotensi untuk menghasilkan efek langkah pendek yang positif. Makna inovasi strategis adalah program atau kebijakan inovatif yang cerdas berpotensi menghasilkan dampak jangka panjang yang positif tetapi belum terbukti implementatif di lapangan. Makna inovatif produktif adalah program yang cerdas dari segi gagasan, berpotensi menghasilkan dampak jangka pendek yang pasif, terbukti implementasi di lapangan, namun belum cukup meyakinkan untuk jangka panjang. Sedangkan makna lainnya (tidak termasuk ke dalam tiga jenis inovasi) berarti proyek perubahan yang dihasilkan oleh peserta Diklatpim IV Kabupaten Pringsewu bukan merupakan pembaruan suatu ide, gagasan, praktek atau objek/benda yang disadari dan diterima sebagai suatu hal yang baru oleh seseorang atau kelompok untuk diadopsi; baik dalam pengertian Everett M. Rogers maupun Stephen Robbins di atas.

Sebanyak 7 (tujuh) jenis proyek perubahan masuk kategori kreatif karena belum menunjukkan praktek positif di lapangan, cerdas dari segi gagasan dan berpotensi untuk menghasilkan efek langkah jangka pendek yang positif. Mengapa tidak bisa mencapai manfaat jangka panjang? Karena gagasan tersebut dengan sendirinya tidak bisa diimplementasikan apabila terjadi tiga keadaan, yaitu apabila sistem penggajian (judul 3 dan 31) yang ditetapkan oleh pemerintah pusat mengalami perubahan struktur, apabila prsyarat pendukung (fasilitas hardware dan software) tidak tersedia (judul $13,20,22)$, serta lembaga daerah yang ada sebagai subyek dan obyek inovasi berubah kedudukan atau mengalami restrukturisasi oleh kewenangan pemerintah pusat (judul 4).

Sebanyak 5 (lima) judul proyek perubahan peserta Diklatpim IV Kabupaten Pringsewu masuk kategori inovatif yang bermanka cerdas dalam sisi gagasan, berpotensi menghasilkan dampak jangka panjang yang positif tetapi belum terbukti implementatif di lapangan karena baru akan dilaksanakan. Temuan menarik justru terlihat pada terjadinya kesenjangan antara inovasi yang masuk kategori inovasi jenis produktif dengan proyek perubahan yang tidak masuk ke dalam ketiga jenis inovasi yang ada. Hanya terdapat 1 (satu) jenis proyek perubahan yang masuk inovasi jenis produktif, sebaliknya terdapat 20 (dua puluh) proyek perubahan yang tidak masuk dalam kategori inovasi karena seluruhnya merupakan tugas pokok dan fungsi dari satuan kerja perangkat kerja daerah di mana peserta Diklatpim IV mengabdi selama ini (asal instansi). 


\section{SIMPULAN DAN SARAN}

\section{Simpulan}

Apabila munculnya inovasi daerah sebagaimana diatur dalam UU 23 Tahun 2014 Pasal 386-390 mengandalkan ukuran dari munculnya kreatifitas peserta Diklatpim IV (fokus kriteria kepemimpinan unit pemerintahan), maka untuk kasus di Kabupaten Pringsewu inovasi daerah tersebut masih belum akan terjadi. Dikaitkan dengan enam kelompok inovasi, sebagian besar proyek perubahan peserta Diklatpim IV Kabupaten Pringsewu (14 judul) hanya masuk kategori penambahan dan atau penguatan dengan kata kunci “optimalisasi”. Sedikit judul (hanya 2 judul) yang masuk kategori penyusunan kembali. Sedangkan pada kategori penggantian, perubahan, dan penghapusan hampir tidak ditemui jenis proyek perubahan yang relevan.

Proyek perubahan yang dihasilkan oleh peserta diklat masih berkisar pada upaya optimalisasi, bukan pengembangan. Artinya, upaya tersebut sangat mungkin sudah dijalankan di tempat (kabupaten/kota/ provinsi) lain apabila dilakukan kajian pembanding. Selain itu, kreatifitas yang muncul dalam laporan proyek perubahan sebagian besar pejabat eselon IV juga masih berkisar pada optimalisasi administratif yang juga sangat mungkin hal tersebut sudah diamanatkan dalam sekian banyak aturan teknis yang dikeluarkan pemerintah (pusat) apabila dilakukan kajian regulasi. Oleh karena itu, proyek perubahan dalam Diklatpim IV hanya merupakan kreatifitas individu dalam menjalankan tupoksi di unit kerja sehingga belum merupakan inovasi pada unit kerja sebagai dasar munculnya inovasi daerah sebagaimana diatur dalam UU 23 Tahun 2014.

Bahkan, Hanya terdapat 1 (satu) jenis proyek perubahan yang masuk inovasi jenis produktif, sebaliknya terdapat 20 (dua puluh) proyek perubahan yang tidak masuk dalam kategori inovasi karena seluruhnya merupakan tugas pokok dan fungsi dari satuan kerja perangkat kerja daerah di mana peserta Diklatpim IV mengabdi selama ini (asal instansi). Temuan tersebut membuktikan bahwa hasil proyek perubahan/inovasi dari peserta Diklatpim IV Kabupaten Pringsewu belum bisa menjadi gambaran sebagai latar belakang proyeksi munculnya inovasi daerah melalui faktor ide/gagasan kepemimpinan daerah.

\section{Saran}

Penyelenggaraan Diklatpim bukan merupakan satu-satunya faktor untuk menilai porspek (peluang) munculnya inovasi daerah. Hal tersebut merupakan salah satu kelemahan dari penelitian ini. Oleh karena itu, secara akademik, tentu 
terdapat variabel-variabel atau faktorfaktor lain sebagai ukuran atau dasar menilai porspek (peluang) munculnya inovasi daerah, selain pada aspek kepemimpinan melalui penyelenggaraan diklatpim sebagai kasus dalam penelitian ini.

Selain itu, melakukan kajian pembanding dengan hasil proyek perubahan di kabupaten/kota lain serta melakukan kajian regulasi terhadap usulan proyek perubahan peserta Diklatpim perlu dilakukan untuk menilai unsur kebaruan terhadap kreatifitas sehingga seleksi jenis inovasi dapat dilakukan sejak para peserta mengajukan judul proyek perubahan. Selain itu, pasal 387 UU No. 23 Tahun 2014 disebutkan bahwa dalam merumuskan kebijakan inovasi, pemerintahan daerah mengacu pada 8 prinsip: peningkatan efisiensi; perbaikan efektivitas; perbaikan kualitas pelayanan; tidak menimbulkan konflik kepentingan; berorientasi kepada kepentingan umum; dilakukan secara terbuka; memenuhi nilai-nilai kepatutan; dan dapat dipertanggungjawabkan hasilnya tidak untuk kepentingan diri sendiri. Oleh karena itu secara praktis, delapan prinsip tersebut seyogyanya juga menjadi dasar dalam perumusan dan atau persetujuan proyek perubahan/inovasi daerah bagi penyelenggara Diklatpim terhadap peserta Diklatpim.

\section{PUSTAKA RUJUKAN}

Abdulhak, I. 2002. Metode Pembelajaran Orang Dewasa. Bandung: Cipta Intelektual.
Creswell, John W. 2010. Research Design: Pendekatan Kualitatif, Kuantiotatif dan Mixed. Yogyakarta: Pustaka Pelajar.

Heifetz, Ronald, Alexander Grashow, dan Marty Linski. 2009. The Practice of Adaptive Leadership Tools and Tactics for Changing Your Organization and The World. Massachusetts: Harvard Business School Publishing.

Kumorotomo, Wahyudi \& Widaningrum, Ambar. 2010, Reformasi Aparatur Negara Ditinjau Kembali. Yogyakarta: Gava Media dan JMKP \& MAP UGM.

Noor, Irwan. 2013. Desain Inovasi Pemerintahan Daerah. Malang: UB Press.

Nugraha, Safri dkk. 2007. Hukum Administrasi Negara. Jakarta: CLGS-FH Universitas Indonesia.

Purwanto, M. Ngalim. 2000. PrinsipPrinsip dan Teknik Evaluasi. Bandung: PT Remaja Rosdakarya.

Robbins, Stephen P. 1994. Teori Organisasi: Struktur Desain dan Aplikasi. Jakarta: Arcan.

Rogers, Everett M. 1983. Diffusion on Inovation: Third Edition. New York: The Free Press.

Rogers, Everett M. 2003. Diffusion on Inovation: Five Edition. New York: The Free Press.

Yulk, Gary. 2010. Kepemimpinan dalam Organisasi, Edisi KeLima. Jakarta: PT. Indeks. 